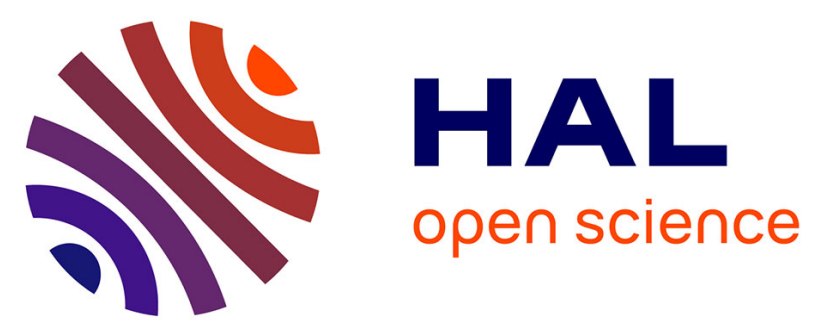

\title{
Assessing the genotoxicity of two commonly occurring byproducts of water disinfection: chloral hydrate and bromal hydrate
}

Tarek Manasfi, Michel de Méo, Carole Di Giorgio, Bruno Coulomb, Jean-Luc Boudenne

\section{To cite this version:}

Tarek Manasfi, Michel de Méo, Carole Di Giorgio, Bruno Coulomb, Jean-Luc Boudenne. Assessing the genotoxicity of two commonly occurring byproducts of water disinfection: chloral hydrate and bromal hydrate. Mutation Research/Mutation Research Genomics, 2017, 813, pp.37-44. 10.1016/j.mrgentox.2016.11.009 . hal-01435494

\section{HAL Id: hal-01435494 \\ https://hal.science/hal-01435494}

Submitted on 19 Jan 2017

HAL is a multi-disciplinary open access archive for the deposit and dissemination of scientific research documents, whether they are published or not. The documents may come from teaching and research institutions in France or abroad, or from public or private research centers.
L'archive ouverte pluridisciplinaire HAL, est destinée au dépôt et à la diffusion de documents scientifiques de niveau recherche, publiés ou non, émanant des établissements d'enseignement et de recherche français ou étrangers, des laboratoires publics ou privés. 


\section{Accepted Manuscript}

Title: Assessing the genotoxicity of two commonly occurring byproducts of water disinfection: chloral hydrate and bromal hydrate

Author: Tarek Manasfi Michel De Méo Carole Di Giorgio Bruno Coulomb Jean-Luc Boudenne

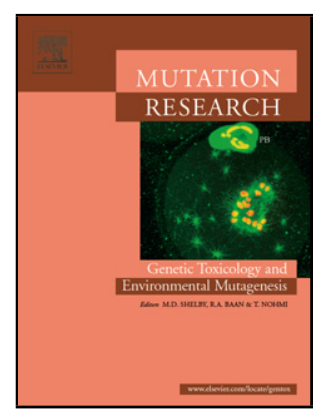

PII:

DOI:

Reference:

S1383-5718(16)30210-8

MUTGEN 402792

To appear in: $\quad$ Mutation Research

Received date: $\quad$ 12-7-2016

Revised date: 22-11-2016

Accepted date: $\quad$ 22-11-2016

Please cite this article as: Tarek Manasfi, Michel De Méo, Carole Di Giorgio, Bruno Coulomb, Jean-Luc Boudenne, Assessing the genotoxicity of two commonly occurring byproducts of water disinfection: chloral hydrate and bromal hydrate, Mutation Research/Genetic Toxicology and Environmental Mutagenesis http://dx.doi.org/10.1016/j.mrgentox.2016.11.009

This is a PDF file of an unedited manuscript that has been accepted for publication. As a service to our customers we are providing this early version of the manuscript. The manuscript will undergo copyediting, typesetting, and review of the resulting proof before it is published in its final form. Please note that during the production process errors may be discovered which could affect the content, and all legal disclaimers that apply to the journal pertain. 


\title{
Assessing the genotoxicity of two commonly occurring byproducts of water disinfection: chloral hydrate and bromal hydrate
}

Tarek Manasfi ${ }^{\mathrm{a}}$, Michel De Méo ${ }^{\mathrm{b}}$, Carole Di Giorgio $^{\mathrm{b}}$, Bruno Coulomb $^{\mathrm{a}}$, Jean-Luc Boudenne $^{\mathrm{a}}$

\author{
${ }^{a}$ Aix Marseille Université, CNRS, LCE UMR 7376, 13331 Marseille, France \\ (E-mail: tarek.manasfi@univ-amu.fr; bruno.coulomb@univ-amu.fr; jean-luc.boudenne@univ-amu.fr) \\ bAix Marseille Université, CNRS, IRD, Avignon Université, IMBE UMR 7263, Laboratoire de \\ Mutagénèse Environnementale, 13385, Marseille, France \\ (E-mail: michel.de-meo@univ-amu.fr; carole.di-giorgio@univ-amu.fr)
}

Corresponding Author: Jean-Luc Boudenne; 3 Place Victor Hugo-Case 29, 13331 Marseille, France; Phone: +33413551031; Email: jean-luc.boudenne@univ-amu.fr

\section{Highlights}

- Genotoxicity of chloral hydrate and bromal hydrate investigated via 3 in vitro assays

- Chloral hydrate not statistically exhibiting significant genotoxic effects

- Mutagenic activity of bromal hydrate in the Salmonella strain TA100

- Significant DNA lesions in CHO cells induced by bromal hydrate

- Higher genotoxicities of brominated DBPs in comparison to chlorinated species

\begin{abstract}
Water disinfection treatments result in the formation of disinfection byproducts (DBPs) that have been linked to adverse human health outcomes including higher incidence of bladder and colorectal cancer. However, data about the genotoxicity of DBPs is limited to only a small fraction of compounds. Chloral hydrate $(\mathrm{CH})$ and bromal hydrate $(\mathrm{BH})$ are two trihaloacetaldehydes commonly detected in disinfected waters, but little is known about their genotoxicity, especially $\mathrm{BH}$.
\end{abstract}


We investigated the genotoxicity of $\mathrm{CH}$ and $\mathrm{BH}$ using a test battery that includes three in vitro genotoxicity assays.

We conducted the Ames test using Salmonella bacterial strains TA97a, TA98, TA100 and TA102, and the alkaline comet assay and the micronucleus test both using Chinese hamster ovary cells. We carried out the tests in the absence and presence of the metabolic fraction S9 mix.

$\mathrm{CH}$ did not exhibit statistically significant genotoxic effects in any of the three assays. In contrast, BH exhibited mutagenic activity in the Salmonella strain TA100 and induced statistically significant DNA lesions in CHO cells as appeared in the comet assay. The genotoxic potential of $\mathrm{BH}$ in both assays decreased in the presence of the metabolic fraction $\mathrm{S} 9 \mathrm{mix}$. $\mathrm{BH}$ did not induce chromosomal damage in CHO cells.

Our results show that $\mathrm{BH}$ exhibited genotoxic activity by causing mutations and primary DNA damage while $\mathrm{CH}$ did not induce genotoxic effects. Our findings highlight concerns about the higher genotoxicity of brominated DBPs in comparison to their chlorinated analogues.

\section{Introduction}

One of the most significant public health advances of the twentieth century was the adoption of drinking water disinfection in many countries [1]. This practice has sharply reduced the incidence of infectious diseases such as cholera, typhoid, and dysentery [2,3]. After this dramatic success, disinfection practices have been introduced into swimming pools and other recreational water venues to ensure the elimination of pathogenic microorganisms and the prevention of waterborne disease outbreaks [4]. However, disinfection treatments result in the undesirable formation of chemical contaminants known as disinfection byproducts (DBPs), in consequence 
to reactions taking place between disinfectants and organic matter present in water $[5,6]$.

Exposure to DBPs in humans can take place through ingestion of drinking water or inhalation and dermal absorption during showering or swimming [7-10]. Many studies have suggested associations between exposure to DBPs and adverse health effects. Increased incidence of asthma [11], bladder cancer [12,13], and colorectal cancer [14] have been reported. Adverse pregnancy outcomes such as spontaneous abortions [15], stillbirth [16], and fetal growth restriction [17] have also been noted. To date, more than six hundred DBPs including trihalomethanes, haloacids, halonitriles, haloaldeydes, haloketones, halonitromethanes, haloamines, haloamides, haloalcohols, and halobenzoquinones have been identified in disinfected waters $[9,18-23]$. Several laboratory-controlled studies have been conducted to evaluate potential toxicities of DBPs providing evidence about cytotoxic, genotoxic, carcinogenic and teratogenic potentials [20, 24-28]. However, the toxicological data are limited to only a small fraction of identified DBPs. In consequence, many DBPs that have been detected in disinfected waters remain with unknown toxicological profiles. Chloral hydrate and bromal hydrate, the hydrated forms of trichloroacetaldehyde and tribromoacetaldehyde respectively, belong to the chemical class of haloacetaldehydes. This class of DBPs has been reported to be one of the most abundant DBP classes by weight $[19,25,29,30]$. Occurrence studies have shown that the predominant trhihaloacetaldehyde in chlorinated waters is chloral hydrate, while bromal hydrate is the predominant trihaloacetaldehyde in chlorinated waters containing high levels of bromide $[19,31]$. In a recent study, $\mathrm{BH}$ was detected as one of the degradation byproducts of benzophenone-3, a UV filter commonly used in sunscreens, in chlorinated swimming pools filled with seawater [32]. 
Toxicokinetic studies have shown that $\mathrm{CH}$ is rapidly absorbed after oral administration, and enters the liver where it undergoes extensive metabolism in rodents [33,34] and in humans $[35,36]$. Studies of the potential carcinogenicity of $\mathrm{CH}$ in mice have demonstrated that it is able to induce hepatocellular adenomas and carcinomas, and exposure to $\mathrm{CH}$ has been associated with increases in malignant lymphoma and adenoma of the pituitary gland [37-39]. However, there was still no persuasive evidence to connect chloral hydrate exposure and the development of cancers in humans [40]. $\mathrm{CH}$ was also found to induce significant aneugenic effects in mice [41]. Furthermore, micronuclei were produced in germ cells of male mice treated intraperitoneally with $\mathrm{CH}$ [42]. $\mathrm{CH}$ was also reported to be able to lead to chromosomal loss in mouse spermatids [43] and in human lymphocytes [44]. Nevertheless, most of the investigations incorporated only one or two in vitro assays [25,45] and results from genotoxicity assessment of $\mathrm{CH}$ remain inconclusive. Concerning $\mathrm{BH}$, although little is known about its toxicity, the U.S. Environmental Protection Agency (EPA) included this compound to the list of priority DBPs to be monitored in a nationwide occurrence study [46] due to anticipations of potential toxicity based on alarming structure-activity relationships [47]. To address this scarcity of data, we analyzed the genotoxicity of $\mathrm{CH}$ and $\mathrm{BH}$ using a battery of three genotoxicity assays, namely the Ames test, the comet assay, and the micronucleus assay. The use of a test battery is critical since no single genotoxicity test is capable of detecting all genotoxic mechanisms [48]. We performed the three assays in the absence and presence of the metabolic activation fraction S9 mix to assess the effects of metabolic reactions on the toxicity of the two compounds. 


\section{Methods}

\section{Chemicals}

The identifiers and structures of $\mathrm{CH}$ and $\mathrm{BH}$ are shown in Table 1. $\mathrm{CH}$ (crystallized, $\geq 98 \%$ ) was obtained from Sigma-Aldrich (China). BH was prepared by adding tribromoacetaldehyde (bromal, Sigma-Aldrich, UK, 97\% purity), to ultrapure water and then recrystallizing the product from a small volume of water. Ultrapure water was produced from a Millipore water system

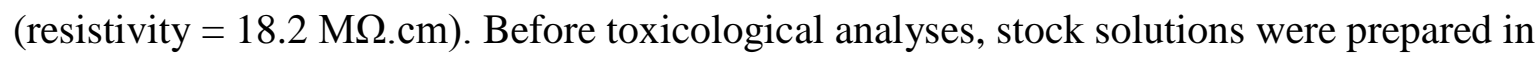
dimethyl sulfoxide (DMSO, Chromasolv plus, $\geq 99.7 \%$ ) obtained from Sigma-Aldrich (UK) and were immediately stored in amber glass vials at $-80^{\circ} \mathrm{C}$.

\section{Metabolic activation mixture (S9 Mix)}

The metabolic activation mixture was a $9000 \mathrm{~g}$ centrifuged supernatant of a liver homogenate (S9). It was prepared from male OFA rats (Charles River Laboratories, France). Five days before sacrifice, the rats were treated with a single injection of Aroclor 1254 (500 mg/kg body weight). The final protein concentration of the $\mathrm{S} 9 \mathrm{mix}$ was $26 \mathrm{mg} / \mathrm{mL}$ as determined by the method of Lowry et al. [49]. In the Salmonella mutagenicity assay, the composition of the metabolic mixture (S9 mix) included 4\% S9, $10 \mathrm{mM}$ glucose-6-phospahate (G6P) and $8 \mathrm{mM}$ nicotinamide adenine dinucleotide phosphate (NADP) (De Méo et al. 1996). In the comet and micronucleus assays, the S9 mix contained 10\% S9, $5 \mathrm{mM}$ G6P, $4 \mathrm{mM}$ NADP, $33 \mathrm{mM}$ KCL and $8 \mathrm{mM} \mathrm{MgCl}_{2}$ diluted in $0.15 \mathrm{M}$ saline phosphate buffer [50].

\section{Cell cultures}

The comet and the micronucleus assays were performed using Chinese Hamster Ovary cells (CHO-K1, ATCC). Cells were grown in McCoy's 5A medium (Sigma-Aldrich, St Quentin 
Fallavier, France) supplemented with $10 \%$ fetal calf serum, $1 \mathrm{mM}$ glutamine and penicillinstreptomycin $(100 \mathrm{U} / \mathrm{mL}$ and $10 \mu \mathrm{g} / \mathrm{mL})$, and incubated in a humidified atmosphere containing $5 \%$ carbon dioxide $\left(\mathrm{CO}_{2}\right)$.

\section{Salmonella/microsome mutagenicity assay}

The Salmonella typhimurium tester strains TA97a, TA98, TA100 and TA102 used in the Ames test were supplied by Prof. B.N. Ames (Berkeley, CA, USA). These strains were used to detect different types of mutations in agreement with the recommendations of Maron and Ames [51]. The strain TA100 is able to detect base-pair substitution mutations. The strains TA97a and TA98 are able to detect frameshift mutations. The strain TA102 detects cross-linking mutagens [52]. The strains were stored at $-80{ }^{\circ} \mathrm{C}$ and regularly checked for genetic markers. The mutagenicity assay was carried out according to Maron and Ames [51], with a modified version of the liquidincubation technique [53]. Salmonella strains were grown in Oxoid Nutrient Broth $\mathrm{N}^{\circ} 2$ with ampicillin $(25 \mu \mathrm{g} / \mathrm{mL})$ for $12 \mathrm{~h}$ at $37^{\circ} \mathrm{C}$ with gentle shaking. After the incubation period, various volumes of solutions of the test substances (four test doses per compound), not exceeding $10 \mu \mathrm{L}$ $(0.5 \%, \mathrm{v} / \mathrm{v})$ to avoid toxicity, were added to $0.1 \mathrm{~mL}$ of the overnight culture and $0.1 \mathrm{~mL}$ of PBS or S9 Mix. The mixtures were incubated either for $60 \mathrm{~min}$ in the dark. Then, $2 \mathrm{~mL}$ of melted top agar containing $0.045 \mathrm{mM}$ histidine and biotin were added, and the mixtures were poured onto Vogel-Bonner (VB) minimal plates. For each series of experiments, negative controls with 5 or

$10 \mu \mathrm{L}$ of DMSO were included to determine the number of spontaneous revertants/plate. Positive controls were also included to ensure the performance of the tester strains: $0.002 \mu \mathrm{g} / \mathrm{plate}$ IRC191 for TA97a, $0.002 \mu \mathrm{g} /$ plate 2,4,7-trinitrofluorenone for TA98, $5 \mu \mathrm{g} / \mathrm{plate}$ NaN3 for TA100, $0.002 \mu \mathrm{g} /$ plate mitomycin C for TA 102. After a 48-h incubation period, revertants were counted with an automatic counter (Scan 1200, Interscience, Saint Nom La Bretèche, France). 
A two-step analysis was performed to interpret the data. The Dunnett test [54] was primarily performed to determine a significant difference between the mean number of induced revertants and the mean number of spontaneous revertants. If the Dunnett test was positive for at least one dose, a nonlinear regression analysis was carried out using an arbitrary model as described previously [54] with TableCurve 2D software (version 5.01, Jandel Scientific Software, San Rafael, CA):

$$
\text { Rev } / \text { plate }=(a+b \times D) \times 2^{-c \times D^{2}}
$$

where Rev/plate is the number of revertants by plate, D is the dose, and a, b, and c are calculated coefficients.

Model significance was based on two criteria: (i) model probability $(P)$ being $<0.05$ and (ii) error probability $\left(P_{\mathrm{E}}\right)$ being $>0.05$. The mutagenic activity $(\mathrm{MA}, \mathrm{rev} / \mu \mathrm{g})$ was defined as the maximal slope of the ascending part of the dose-response curve and was calculated as the first derivative at the origin.

\section{Cytotoxicity assay: WST-1 test}

The cytotoxicities of $\mathrm{CH}$ and $\mathrm{BH}$ in $\mathrm{CHO}$ cells were analyzed using the WST-1-based cytotoxicity assay. The latter is a colorimetric assay that allows the quantitation of cellular cytotoxicity and proliferation based upon the reduction of the tetrazolium salt WST-1 to formazan by cellular dehydrogenases. A total of 50000 cells were seeded in 96-well plates and incubated overnight at $37{ }^{\circ} \mathrm{C}$ with $5 \% \mathrm{CO}_{2}$ in a humidified incubator. A range of concentrations of $\mathrm{BH}$ and $\mathrm{CH}$ was incorporated in triplicate cultures (final DMSO concentration less than $0.2 \%$ ), and cells were incubated at $37^{\circ} \mathrm{C}$ for $2 \mathrm{~h}$. At the end of the incubation period, cultures were submitted to three successive washes with PBS and incubated in 10\% WST1 (Roche Diagnostics, Meylan, France) in culture medium for $30 \mathrm{~min}$. Cell viability was evaluated by the 
assessment of WST1 absorbance at $450 \mathrm{~nm}$ in a microplate reader (Infinite M200 Pro, Tecan, Lyon, France).

\section{Alkaline comet assay}

The alkaline comet assay was performed as described by Tice et al. [55] with slight modifications [56]. A total of $50000 \mathrm{CHO}$ cells were plated 24-well plates and incubated for 24 $\mathrm{h}$ at $37{ }^{\circ} \mathrm{C}$ in a humidified atmosphere containing $5 \% \mathrm{CO}_{2}$. Two sets of experiments were performed. In the first set of experiments, cells were rinsed and incubated into culture medium containing $\mathrm{BH}$ or $\mathrm{CH}$ solutions in duplicate. In the second set of experiments, cells were rinsed and incubated into culture medium containing $10 \% \mathrm{~S} 9$ mix, and $\mathrm{BH}$ or $\mathrm{CH}$ solutions. Two negative controls were added to determine the background DNA-damage levels in CHO cells: the culture medium control and a $1 \%$ DMSO control, corresponding to the maximal concentration of DMSO incorporated into cell cultures. Two positive controls with the wellknown genotoxic compound Methyl methanesulfonate (MMS) with and without S9 Mix were also added.

After a contact period of $2 \mathrm{~h}$, the cells were embedded in low-melting-point agarose. Lysis, DNA unwinding, and electrophoresis were performed as described previously [57]. Following the electrophoretic run, the slides were neutralized with $0.4 \mathrm{M}$ Tris- $\mathrm{HCl}(\mathrm{pH} 7.4)$, rinsed with ultrapure water, dipped into $100 \%$ methanol (HPLC-grade purity), and dried at room temperature. Staining was performed with ethidium bromide solution $(2 \mu \mathrm{g} / \mathrm{mL})$, and the slides were examined at $250 \times$ magnification using a BX53 fluorescence microscope (Olympus France, Rungis, France). Image analysis was performed using the Komet software (version 6.0, Andor Technology, Belfast, Northern Ireland) on 100 randomly selected cells (50 cells for each of two replicate slides). DNA damage was expressed as Olive tail moment (OTM, arbitrary units) [50]. 
The calculated OTM values were distributed into 40 classes between the minimal and the maximal OTM values. A nonlinear regression analysis was performed on the normalized distribution frequencies using a $\chi^{2}$ function with TableCurve 2D (version 5.01, Systat Software, Erkrath, Germany). The calculated degree of freedom (n) for the function, named OTM $\chi^{2}$, was assumed to be a quantitative measure of the level of DNA damage in the sample [58]. The test was considered positive when a dose-response relationship could be established between the OTM $\chi^{2}$ and the concentrations of the compound and when one concentration at least induced a significant increase of OTM $\chi^{2}$ by the comparison of means $(p<0.05)$. The genotoxicity was calculated by nonlinear regression analysis with table Curve $2 \mathrm{D}$ using an arbitrary model

$$
G=\frac{a C o}{b+C o}+c
$$

where G: genotoxicity, Co: concentration $(\mathrm{mg} / \mathrm{mL})$ and $\mathrm{a}, \mathrm{b}$, and c: calculated coefficients. The maximal genotoxic activity was defined as the first derivative of the model at the maximal tested dose $(1 \mu \mathrm{g} / \mathrm{mL})$.

\section{Micronucleus assay}

A total of 50,000 CHO-K1 cells was plated in chamber slides and incubated for $24 \mathrm{~h}$ at $37{ }^{\circ} \mathrm{C}$ in a humidified atmosphere containing $5 \% \mathrm{CO}_{2}$. Various concentrations of $\mathrm{BH}$ and $\mathrm{CH}$ solutions were incorporated into duplicate cell cultures. Two negative controls were added to determine the background DNA-damage levels in $\mathrm{CHO}$ cells: the culture medium control and a 1\% DMSO control, corresponding to the maximal concentration of DMSO incorporated into cell cultures. Two positive controls with well-known genotoxic compounds were also included to ensure the sensitivity of the assay: these were $0.06 \mu \mathrm{g} / \mathrm{mL}$ mitomycine $\mathrm{C}$ without $\mathrm{S} 9 \mathrm{Mix}$ and $5 \mu \mathrm{g} / \mathrm{mL}$ benzo[a]pyrene $(\mathrm{BaP})$ with S9 Mix. 
After a 3-h exposure, cells were rinsed with PBS and incubated in fresh medium containing cytochalasin B $(3 \mu \mathrm{g} / \mathrm{mL})$ for an additional $22 \mathrm{~h}$ period to stop cytokinesis. At the end of the incubation period, cells were submitted to two successive washes with PBS and fixed with methanol (HPLC purity grade solvent). The slides were air dried and stained with 5\% Giemsa stain in Milli-Q water for $15 \mathrm{~min}$.

The Cytokinesis Blocked Proliferation Index (CBPI) was used to select adequate concentrations for the assessment of micronuclei, as it has been considered a measure of cytotoxicity [58]. CBPI was determined by scoring the number of mononucleated (M1), binucleated (M2), and trinucleated (M3) cells among 500 Giemsa-stained cells with well-preserved cytoplasm: CBPI = $(\mathrm{M} 1+2 \times \mathrm{M} 2+3 \times \mathrm{M} 3) / 500$.

The Proliferative Index (CI\%), i.e. the percentage of cell replication inhibition, was calculated using the following formula: PI\% $=100-\left\{100 \times\left(\mathrm{CBPI}_{\text {test material }}-1\right) /\left(\mathrm{CBPI}_{\mathrm{DMSO} \text { control}}-1\right)\right.$. After this step, only the doses inducing a decrease of less than $50 \%$ of PI\% as compared to the negative control were taken into account for counting micronuclei. Micronuclei were identified according to the morphological criteria previously defined by Kirsch-Volders et al. [58]. Statistical differences between negative controls and treated samples were determined using the $\chi 2$ test. The micronucleus assay was considered positive when a dose-response relationship could be established between micronucleated cells rates and concentrations, and when at least one concentration induced a significant increase of micronucleated cells as compared to the DMSOcontrol culture.

\section{Results}

\section{The Ames test}


We evaluated the capacity of $\mathrm{CH}$ and $\mathrm{BH}$ to induce mutations in DNA using the Ames test in four Salmonella tester strains: TA97a, TA98, TA100, and TA102. The assay was carried out in the absence and presence of exogenous metabolic activation ( $\mathrm{S} 9 \mathrm{mix}$ ). As shown in Table 2, $\mathrm{CH}$ did not exhibit mutagenic effects in the tested strains, unlike $\mathrm{BH}$, which induced mutagenic activity in the strain TA100. The results of the regression analyses for the dose-response relationship of $\mathrm{BH}$ in the presence and absence of $\mathrm{S} 9$ mix are displayed in Figure 1. The mutagenic activity calculated for BH was $19.5 \mathrm{Rev} / \mu \mathrm{g}(5.8 \mathrm{Rev} / \mathrm{nmol})$ and $7.9 \mathrm{rev} / \mu \mathrm{g}(2.4$ Rev/nmol) in the absence and presence of the metabolic fraction S9 mix, respectively. Thus, the presence of the metabolic activation system induced about $60 \%$ decrease in the mutagenicity of $\mathrm{BH}$.

\section{Cytotoxicity assay on CHO cells}

We examined the cytotoxicity of $\mathrm{CH}$ and $\mathrm{BH}$ in $\mathrm{CHO}$ using the WST-1-based assay. Figure 2 displays the cellular viability as a function of concentration for $\mathrm{CH}$ and $\mathrm{BH}$. $\mathrm{CH}$ induced a slight decrease in the viability of $\mathrm{CHO}$ cells at concentrations up to $1.0 \mathrm{mg} / \mathrm{mL}$. In contrast, $\mathrm{BH}$ exhibited cytotoxic activity at levels as low as $5.0 \mu \mathrm{g} / \mathrm{mL}$.

\section{The comet assay}

We examined the capacity of $\mathrm{CH}$ and $\mathrm{BH}$ to induce DNA damage in $\mathrm{CHO}$ cells using the comet assay. $\mathrm{CHO}$ cells were exposed to $\mathrm{CH}$ and $\mathrm{BH}$ at different concentrations for $2 \mathrm{~h}$ in the absence and in the presence of the metabolic mixture S9 mix. Since $\mathrm{BH}$ displayed cytotoxicity in $\mathrm{CHO}$ cells as assessed by the WST-1 test, the used concentrations were selected to maintain cell viability above $95 \%$. The results of the comet assay are reported in Figure 3A for OTM values and in Figure 3B for OTM $\chi^{2}$ values. Parametric analyses were limited to OTM $\chi^{2}$ values as OTM values were not normally distributed (Fig 3A, box plot). $\mathrm{CH}$ did not induce any significant 
DNA strand breaks in the absence or in the presence of $\mathrm{S} 9 \mathrm{mix}$ up to $1 \mathrm{mg} / \mathrm{mL}$. On the contrary, BH induced statistically significant DNA lesions at the three tested concentrations in the absence of metabolic activation only. Modeling of the dose-response curve for BH is displayed in Figure 4. The genotoxicity (G) was 3.68 OTM $\chi^{2}$ units $/ \mu \mathrm{g}\left(\mathrm{r}^{2}=0.96, p<10^{-5}, P_{E}=0.07\right)$.

\section{The micronucleus assay}

We examined the ability of $\mathrm{CH}$ and $\mathrm{BH}$ to induce chromosomal damage by conducting the micronucleus assay in $\mathrm{CHO}$ cells. Cells were exposed for $3 \mathrm{~h}$ to a range of concentrations of $\mathrm{CH}$ and $\mathrm{BH}$ in the absence and the presence of the metabolic activation fraction S9 mix. Table 3 shows the proliferative index (PI), the mean number of micronucleated binucleated cells (MBCs), and the p-values. PI gives an estimation of the antiproliferative/cytotoxic activity of compounds. PI values beyond 50\% mean that evaluation of chromosomal damage would not be possible at the concentrations in question. These critical concentrations were 50 and $25 \mu \mathrm{g} / \mathrm{mL}$ for $\mathrm{CH}$ and 2.5 and $5.0 \mu \mathrm{g} / \mathrm{mL}$ for BH without and with the $\mathrm{S} 9$ mix, respectively. The number of MBCs was obtained by counting micronucleated binucleated cells per 1000 cells. No significant increases in micronucleated cell rates could be observed for both compounds. Thus, $\mathrm{CH}$ and $\mathrm{BH}$ did not exhibit any clastogenic or aneugenic effects against $\mathrm{CHO}$ cells.

\section{Discussion}

Several epidemiologic studies have suggested that exposure to DBPs is associated with increased incidence of cancer, particularly bladder and colorectal cancers [12-14]. The analysis of genotoxicity of DBPs allows identifying the chemical species that could be responsible for carcinogenicity [48]. Genotoxicity testing detects carcinogens that are thought to act primarily via a mechanism involving direct genetic damage [48]. $\mathrm{CH}$ has been frequently detected as a predominantly occurring DBP in chlorinated drinking and swimming pool waters $[19,25,59]$. In 
the presence of relatively high levels of bromide, brominated DBPs are formed upon disinfection with chlorine [60]. $\mathrm{BH}$ has been detected as the predominant trihaloacetaldehyde in chlorinated seawater swimming pools where high bromide contents are found [19]. BH has been also detected as the major haloacetaldehyde in chloraminated drinking water originating from bromide-rich source water $[25,46]$. Although some studies have investigated the genotoxicity of $\mathrm{CH}$, findings have not been consistent $[25,45,61,62]$. This could be due the equivocal responses exhibited by $\mathrm{CH}$ leading to different interpretations (as slightly genotoxic or not genotoxic) and therefore equivocal conclusions. In addition, very little is known about the toxicity of BH for which two genotoxicity investigations have reported positive genotoxic effects in the comet assay $[25,45]$. However, additional studies incorporating a battery of genotoxicity assays seem necessary to obtain further knowledge about the toxicity of $\mathrm{CH}$ and $\mathrm{BH}$ and the mechanisms of action involved in any eventual genotoxicity. We tested the potential of $\mathrm{CH}$ and $\mathrm{BH}$ to induce genetic damage using the Ames test, the comet assay, and the micronucleus assay. As reviewed by Claxton et al. [63], the Ames test serves as a reliable tool in screening for mutagenic agents. Extensive reviews have shown that many compounds that are mutagenic in the Ames test are rodent carcinogens [48]. The comet test allows measuring DNA single- and double-strand breaks and detecting alkali labile sites $[64,65]$. The induction of micronuclei has been demonstrated to be an effective biomarker of cancer risk [66]. The in vitro micronucleus assay detects reliably chromosomal breaks and aneuploidy [67-68]. The combination of the three assays could provide insights into the mechanism of action involved in genotoxicity.

As far as we know, this study evaluates for the first time the mutagenicity of $\mathrm{BH}$ using the Salmonella Ames test and the genotoxicity of both $\mathrm{CH}$ and $\mathrm{BH}$ using the micronucleus test in CHO cells. To take into account the effects of metabolic reactions on the genotoxicity of the two 
compounds, we carried out the tests in the presence and absence of metabolic activation fraction S9 mix.

According to our findings, $\mathrm{CH}$ did not exhibit genotoxic activity in any of the three assays. These results are consistent with previous studies reporting the lack of genotoxicity indications for $\mathrm{CH}$ in the comet assay using CHO cells $[25,61]$. Similarly, in an evaluation of the mutagenicity of $\mathrm{CH}$ in vitro and in vivo, authors reported the absence of indications for a mutagenic potential [62]. In the same way, negative results have been reported in the micronucleus test where $\mathrm{CH}$ failed to induce micronuclei or showed very weak effects in human lymphocytes [69], mouse lymphoma cells [70], TK6 cells and human peripheral blood lymphocytes [45]. Some investigations reporting positive genotoxicity findings have been reported in the literature for $\mathrm{CH}$. Using the comet assay, Liviac et al. [45] reported genetic damages caused by $\mathrm{CH}$ in TK6 cells. In the micronucleus assay, $\mathrm{CH}$ induced aneuploidy in $\mathrm{CHO}$ cells at high doses [71] and induced micronuclei in mouse spermatocytes [41-43], and human fibroblasts [72].

Concerning BH, our findings show that it induced mutagenic activity in the Ames test, caused genetic damage in $\mathrm{CHO}$ cells in the comet assay, but failed to induce micronuclei in the $\mathrm{CHO}$ cells. In the Ames test, positive results were limited to the TA100 strain. The hisG46 marker in TA100 results from the substitution of a leucine (GAG/CTC) by a proline (GGG/CCC). This mutation is reverted to the wild-type strain by mutagens that cause base-pair substitution mutations at one of the GC pairs. Among them, brominated reactive byproducts may combine with $\mathrm{G}$ to form a small adduct and thus can revert the mutation. The genotoxicity of $\mathrm{BH}$ decreased considerably when metabolic activation was incorporated suggesting the formation of less toxic metabolites. Our findings are consistent with previous investigations reporting genotoxic activity for $\mathrm{BH}$ detected using the comet assay in $\mathrm{CHO}$ cells [25], human lymphocytes 
and TK6 cells [45]. Moreover, a negative response has been previously reported for BH using the micronucleus test in human lymphocytes and TK6 cells [45]. Overall, the results of the three assays imply that the mechanism of toxicity of $\mathrm{BH}$ involves the induction of mutations and primary DNA lesions but not chromosomal damage.

The present study corroborates previous investigations highlighting the higher genotoxic potential for brominated DBPs in comparison to their chlorinated analogs $[20,25,27,73,74]$. This trend has been reported for several chemical classes of DBPs including THMs, HAAs, and HANs. The difference in genotoxic potentials between brominated and chlorinated species has been attributed to differences in the leaving tendency of the halogens in the alkyl halide [25, $27,28,75]$. These findings highlighting the toxicity of brominated DBPs are of relevance to public health since epidemiologic investigations have associated statistically significant increases in risks of birth defects with residence in areas where water supply had high levels of brominated DBPs [76].

One of the limitations of this study was the lack of data about the pharmacokinetics of $\mathrm{BH}$, so its absorption and fate once introduced to biological media remain unknown. Also, the present study is limited to genotoxicity assessment, yet there are other events that could lead to carcinogenesis besides genotoxic effects. In addition, the study is limited to a genotoxicity endpoint, but DBPs could cause other toxicological effects and be implicated in some pathological conditions. Despite these limitations, the in vitro assays used here are reliable tools to detect genotoxic compounds such as $\mathrm{BH}$ and hence to highlight the importance of limiting the exposure of individuals to DBPs. 


\section{Conclusions}

Our findings show that $\mathrm{CH}$ did not induce any genotoxic effects using the Ames test, the comet assay, and the micronucleus test, while BH was mutagenic in the Salmonella assay and caused genomic damage in the comet assay but not in the micronucleus test. These results imply that the mechanism of genotoxicity of $\mathrm{BH}$ involves inducing mutations and DNA damage but not chromosomal aberrations. The genotoxicity of $\mathrm{BH}$ decreased in the presence of metabolic fractions suggesting the formation of less genotoxic metabolites. Furthermore, our findings highlighting the toxicity of brominated DBPs are of relevance to public health since epidemiologic investigations have associated statistically significant increases in risks of birth defects with residence in areas where water supply had high levels of brominated DBPs [76]. This study providing evidence of the genotoxic potential of a commonly occurring DBP emphasize the importance of reducing the levels of DBPs, particularly brominated species, in disinfected waters. Further research examining the genotoxicity of other DBPs is warranted to identify genotoxic DBPs that could be responsible for the reported adverse health effects.

Acknowledgments: T.M. acknowledges the French Ministry of Higher Education and Research for his doctoral scholarship.

\section{References}

[1] G.A. Boorman, V. Dellarco, J.K. Dunnick, R.E. Chapin, S. Hunter, F. Hauchman, H. Gardner, M. Cox, R.C. Sills. Drinking water disinfection byproducts: review and approach to toxicity evaluation. Environ. Health Persp. 107 (1999) 207-217.

[2] D. Cutler, G. Miller. The Role of Public Health Improvements in Health Advances: The 
Twentieth-Century United States. Demography 42 (2005) 1-22.

[3] J. Orme, C.S. Mullin, E.V. Ohanian. Health effects of disinfectants and disinfection byproducts: a regulatory perspective. Water Chlorination 6 (1990) 75-86.

[4] World Health Organisation. 2006. Guidelines for safe recreational water environments: Volume 2. Swimming pools and similar environments. 2: 146.

[5] A. Kanan, T. Karanfil. Formation of disinfection by-products in indoor swimming pool water: The contribution from filling water natural organic matter and swimmer body fluids. Water Res. 45 (2011) 926-932.

[6] J. Rook. Formation of haloforms during chlorination of natural waters. J. Water Treatment Examination 23 (1974) 234-243.

[7] L.C. Backer, D.L. Ashley, M.A. Bonin, F.L. Cardinali, S.M. Kieszak, J.V. Wooten. Household exposures to drinking water disinfection by-products: whole blood trihalomethane levels. J. Expo. Anal. Environ. Epidemiol. 10 (2000) 321-326.

[8] A.M. Miles, P.C. Singer, D.L. Ashley, M.C. Lynberg, P. Mendola, P.H. Langlois, J.R. Nickols. Comparison of Trihalomethanes in Tap Water and Blood. Environ. Sci. Technol. 36 (2002) 1692-1698.

[9] S.D. Richardson, D.M. DeMarini, M. Kogevinas, P. Fernandez, E. Marco, C. Lourencetti, C. Balleste, D. Heederick, K. Meliefste, A.B. McKague. What's in the Pool? A Comprehensive Identification of Disinfection By-products and Assessment of Mutagenicity of Chlorinated and Brominated Swimming Pool Water. Environ. Health Perspect. 118 (2010) 1523-1530.

[10] X. Xu, C.P. Weisel. Dermal uptake of chloroform and haloketones during bathing. J. Expo. Anal. Environ. Epidemiol. 15 (2005) 289-296.

[11] A. Bernard, S. Carbonnelle, C. de Burbure, O. Michel, M. Nickmilder. Chlorinated pool 
attendance, atopy, and the risk of asthma during childhood. Environ. Health Perspect. 114 (2006) 1567-1573.

[12] C.M. Villanueva, K.P. Cantor, S. Cordier, J.J.K Jaakkola, W.D. King, C.F. Lynch, S. Porru, M. Kogevinas Disinfection byproducts and bladder cancer: a pooled analysis. Epidemiology 15 (2004) 357-367.

[13] C.M. Villanueva, K.P. Cantor, J.O. Grimalt, N. Malats, D. Silverman, A. Tardon, R. GarciaClosas, C. Serra, A. Carrato, G. Castano-Vinyals. Bladder cancer and exposure to water disinfection by-products through ingestion, bathing, showering, and swimming in pools. Am. J. Epidemiol. 165 (2007) 148-156.

[14] M.B. Rahman, T. Driscoll, C. Cowie, B.K. Armstrong. Disinfection by-products in drinking water and colorectal cancer: a meta-analysis. Int. J. Epidemiol. 39 (2010) 733-745.

[15] D.A. Savitz, K.W. Andrews, L.M. Pastore. Drinking water and pregnancy outcome in central North Carolina: Source, amount, and trihalomethane levels. Environ. Health Persp. 103 (1995) 592-596.

[16] L. Dodds, W. King, A.C. Allen, B.A. Armson, D.B. Fell, C. Nimrod. Trihalomethanes in public water supplies and risk of stillbirth. Epidemiology 15 (2004) 179-186.

[17] N. Costet, R. Garlantezec, C. Monfort, F. Rouget, B. Gagnière, C. Chevrier, S. Cordier. Environmental and urinary markers of prenatal exposure to drinking water disinfection byproducts, fetal growth, and duration of gestation in the PELAGIE birth cohort (Brittany, France, 2002-2006). Am. J. Epidemiol. 175 (2012) 263-275.

[18] S. Chowdhury, K. Alhooshani, T. Karanfil. Disinfection byproducts in swimming pool: Occurrences, implications and future needs. Water Res. 53 (2014) 68-109. 
[19] T. Manasfi, M. De Méo, B. Coulomb, C. Di Giorgio, J.L. Boudenne. Identification of disinfection by-products in freshwater and seawater swimming pools and evaluation of genotoxicity. Environ. Int. 88 (2016) 94-102.

[20] S. Richardson, M. Plewa, E. Wagner, R. Schoeny, D.M. De Marini. Occurrence, genotoxicity, and carcinogenicity of regulated and emerging disinfection by-products in drinking water: A review and roadmap for research. Mutat. Res. Mutat. Res. 636 (2007) $178-242$.

[21] T.L.L. Teo, H.M. Coleman, S.J. Khan. Chemical contaminants in swimming pools: Occurrence, implications and control. Environ. Int. 76 (2015) 16-31.

[22] W. Wang, Y. Qian, J.M. Boyd, M. Wu, S.E. Hrudey, X.F. Li. Halobenzoquinones in swimming pool waters and their formation from personal care products. Environ. Sci. Technol. 47 (2013) 3275-3282.

[23] C. Zwiener, S.D. Richardson, D.M. De Marini, T. Grummt, T. Glauner, F.H. Frimmel. Drowning in Disinfection Byproducts? Assessing Swimming Pool Water. Environ. Sci. Technol. 41 (2007) 363-372.

[24] E.S. Hunter, E.H. Rogers, J.E. Schmid, A. Richard. Comparative effects of haloacetic acids in whole embryo culture. Teratology 54 (1996) 57-64.

[25] C.H. Jeong, C. Postigo, S.D. Richardson, J.E. Simmons, S.Y. Kimura, B.J. Marinas, D. Barcelo, P. Liang, E.D. Wagner, M.J. Plewa. Occurrence and Comparative Toxicity of Haloacetaldehyde Disinfection Byproducts in Drinking Water. Environ. Sci. Technol. 49 (2015) 13749-13759.

[26] M.G. Narotsky, D.S. Best, A. McDonald, E.A. Godin., E.S. Hunter, J.E. Simmons. 
Pregnancy loss and eye malformations in offspring of F344 rats following gestational exposure to mixtures of regulated trihalomethanes and haloacetic acids. Reprod. Toxicol. 31 (2011) 59-65.

[27] M.J. Plewa, E.D. Wagner, M.G. Muellner, K.M. Hsu, S.D. Richardson. Comparative mammalian cell toxicity of N-DBPs and C-DBPs. ACS SYM. SER. 995 (2008) 36-50.

[28] M.J. Plewa, J.E. Simmons, S.D. Richardson, E.D. Wagner. Mammalian cell cytotoxicity and genotoxicity of the haloacetic acids, a major class of drinking water disinfection byproducts. Environ. Mol. Mutagen. 51 (2010) 871-878.

[29] M. Clemens, H.F. Schöler. Halogenated organic compounds in swimming pool water. Zbl. Hyg. Umweltmed. 193 (1992) 91-98.

[30] N. Cimetiere, J. De Laat. Effects of UV-dechloramination of swimming pool water on the formation of disinfection by-products: A lab-scale study. Microchem. J. 112 (2014) 34-41.

[31] S.D. Richardson, A.D. Thruston, S.W. Krasner, H.S. Weinberg. Results of a Nationwide DBP Occurrence Study: Identification of new DPBs of potential health concern. Epidemiology. 13 (2002) S109-S110.

[32] T. Manasfi, V. Storck, S. Ravier, C. Demelas, B. Coulomb, J.L. Boudenne. Degradation Products of Benzophenone-3 in Chlorinated Seawater Swimming Pools. Environ. Sci. Technol. 49 (2015) 9308-9316.

[33] F.A. Beland, T.C. Schmitt, N.F. Fullerton, J.F. Young. Metabolism of chloral hydrate in mice and rats after single and multiple doses. J. Toxicol. Env. Heal. A. 54 (1998) 209-226.

[34] J.L. Merdink, R.D. Stenner, D.K. Stevens, J.C. Parker, R.J. Bull. Effect of enterohepatic 
circulation on the pharmacokinetics of chloral hydrate and its metabolites in F344 rats. J. Toxicol. Env. Heal. A. 57 (1999) 357-368.

[35] T. Zimmermann, M. Wehling, H.U. Schulz. Evaluation of the relative bioavailability and the pharmacokinetics of chloral hydrate and its metabolites. Arzneimittel-Forsch. 48 (1998) $5-12$

[36] J.L. Merdink, L.M. Robison, D.K. Stevens, M. Hu, J.C. Parker, R.J. Bull.Kinetics of chloral hydrate and its metabolites in male human volunteers. Toxicoly 245 (2008) 130-140.

[37] K.S. Rijhsinghani, C. Abrahams, M.A. Swerdlow, T. Ghose, C. Abrahams, K.V.N. Rao. Induction of neoplastic lesions in the livers of C57BL $\times$ C3HF1 mice by chloral hydrate. Cancer Detect. Prev. 9 (1986) 279-288.

[38] F.B. Daniel, A.B. DeAngelo, J.A. Stober, G.R. Olson, N.P. Page. Hepatocarcinogenicity of chloral hydrate, 2-chloroacetaldehyde, and dichloroacetic acid in the male B6C3F1 mouse. Fundam. Appl. Toxicol. 19 (1992) 159-168.

[39] M.H. George, T. Moore, S. Kilburn, G.R. Olson, A.B. DeAngelo. Carcinogenicity of chloral hydrate administered in drinking water to the male $\mathrm{F} 344 / \mathrm{N}$ rat and male B6C3F1 mouse. Toxicol. Pathol. 28 (2000) 610-618.

[40] T. Haselkorn, A.S. Whittemore, N. Udaltsova, G.D. Friedman. Short-term chloral hydrate administration and cancer in humans. Drug Saf. 29 (2006) 67-77.

[41] A. Russo, A.G. Levis. Further evidence for the aneuploidogenic properties of chelating agents: induction of micronuclei in mouse male germ cells by EDTA. Environ. Mol. Mutagen. 19 (1992), 125-131. 
[42] J.W. Allen, B.W. Collins, P.A. Evansky. Spermatid micronucleus analyses of trichloroethylene and chloral hydrate effects in mice. Mutat. Res. 323 (1994) 81-88.

[43] E.V. Nutley, A.C. Tcheong, J.W. Allen, B.W. Collins, M. Ma, X.R. Lowe, J.B. Bishop, D.H. Moore, A.J. Wyrobek. Micronuclei induced in round spermatids of mice after stemcell treatment with chloral hydrate: evaluations with centromeric DNA probes and kinetochore antibodies. Environ. Mol. Mutagen. 28 (1996), 80-89.

[44] P. Vagnarelli, A. De Sario, L. De Carli. Aneuploidy induced by chloral hydrate detected in human lymphocytes with the Y97 probe. Mutagenesis, 5 (1990), 591-592.

[45] D. Liviac, A. Creus, R. Marcos. DNA damage induction by two halogenated acetaldehydes, byproducts of water disinfection. Water Res. 44 (2010) 2638-2846.

[46] H.S. Weinberg, S.W. Krasner, S.D. Richardson, a D. Thruston, EPA The Occurrence of Disinfection By-Products (DBPs) of Health Concern in Drinking Water: Results of a Nationwide DBP Occurrence Study, (2002) 462p. doi:EPA/600/R-02/068.

[47] Y.T. Woo, D. Lai, J.L. Mclain, M.K. Manibusan, V. Dellarco. Use of Mechanism-Based Structure - Activity Relationships Analysis in Carcinogenic Potential Ranking for Drinking Water Disinfection By-Products. Environ. Heal. 110 (2002) 75-87.

[48] U.S. Department of Health and Human Services. 2012. S2(R1) Genotoxicity Testing and Data Interpretation for Pharmaceuticals Intended for Human Use. Guid. Ind. 2:1-31.

[49] O.H. Lowry, N.J. Rosebrough, A.L. Farr, R.J.Randall RJ. Protein measurement with the Folin phenol reagent. J. Biol. Chem. 193 (1951) 265-275.

[50] A. Aouadene, C. Di Giorgio, L. Sarrazin, X. Moreau, L. De Jong, F. Garcia. Evaluation of 
the genotoxicity of river sediments from industrialized and unaffected areas using a battery of short-term bioassays. Environ. Mol. Mutagen. 49 (2008) 283-299.

[51] D.M. Maron, B.N. Ames. Revised methods for the salmonella mutagenicity test. Mutat. Res. 113 (1983) 173-215.

[52] OECD. 1997. Test No. 471: Bacterial Reverse Mutation Test, OECD Publishing, Paris. DOI: http://dx.doi.org/10.1787/9789264071247-en

[53] M. De Méo, M. Laget, C. Di Giorgio, H. Guiraud, A. Botta, M. Castegnaro, G. Dumenil. Optimization of the Salmonella/mammalian microsome assay for urine mutagenesis by experimental designs. Mutat. Res. Genet. Toxicol. 340 (1996) 51-65.

[54] B.S. Kim, B.H. Margolin. Statistical methods for the Ames Salmonella assay: a review. Mutat. Res. Mutat. Res. 436 (1999) 113-122.

[55] R.R. Tice, E. Agurell, D. Anderson, B. Burlinson, A. Hartmann, H. Kobayashi, Y. Miyamae, E. Rojas, J.C. Ryu, Y.F. Sasaki. Single Cell Gel / Comet Assay : Guidelines for In Vitro and In Vivo Genetic Toxicology Testing. Environ. Mol. Mutagen. 35 (2000) 206221.

[56] M. De Méo, M.Laget, M. Castegnaro, G. Duménil. Genotoxic activity of potassium permanganate in acidic solutions. Mutat. Res. Toxicol. 260 (1991) 295-306.

[57] P.L. Olive, J.P. Banánth. Induction and rejoining of radiation-induced DNA single-strand breaks: "tail moment" as a function of position in the cell cycle. Mutat. Res. Repair. 294 (1993) 275-283.

[58] M. Kirsch-Volders, T. Sofuni, M. Aardema, S. Albertini , D. Eastmond, M. Fenech, M. 
Ishidate, S. Kirchner, E. Lorge, T. Morita, H. Norppa, J. Surralles, A. Vanhauwaert, A. Wakata. Report from the in vitro micronucleus assay working group. Mutat. Res. Toxicol. Environ. Mutagen. 540 (2003) 153-163.

[59] J. Lee, M.J. Jun, M.H. Lee, S.W. Eom, K.D. Zoh. Production of various disinfection byproducts in indoor swimming pool waters treated with different disinfection methods. Int. J. Hyg. Environ. Health 213 (2010) 465-474.

[60] G. Hua, D.A. Reckhow, J. Kim. Effect of Bromide and Iodide Ions on the Formation and Speciation of Disinfection Byproducts during Chlorination. Environ. Sci. Technol. 40 (2006) 3050-3056.

[61] M. Kiffe, P. Christen, P. Arni. Characterization of cytotoxic and genotoxic effects of different compounds in $\mathrm{CHO} \mathrm{K} 5$ cells with the comet assay (single-cell gel electrophoresis assay). Mutat. Res. Toxicol. Environ. Mutagen. 537 (2003) 151-168..

[62] J. Leuschner J, F. Leuschner F. Evaluation of the mutagenicity of chloral hydrate in vitro and in vivo. Arzneimittelforschung. 41 (1991) 1101-1103.

[63] L.D. Claxton, G.A. De Umbuzeiro, D.M. DeMarini. The salmonella mutagenicity assay: The stethoscope of genetic toxicology for the 21st century. Environ. Health Persp. 118 (2010) 1515-1522.

[64] A.R. Collins. The comet assay for DNA damage and repair: principles, applications, and limitations. Mol. Biotechnol. 26 (2004) 249-261.

[65] D.W. Fairbairn, P.L. Olive, K.L. O’Neill. The comet assay: a comprehensive review. Mutat. Res. 339 (1995) 37-59. 
[66] A. Matsuoka, N. Yamazaki, T. Suzuki, M. Hayashi, T. Sofuni. Evaluation of the micronucleus test using a Chinese hamster cell line as an alternative to the conventional in vitro chromosomal aberration test. Mutat. Res. Mutagen. Relat. Subj. 272 (1992) 223-236.

[67] I. Decordier, M. Kirsch-Volders. The in vitro micronucleus test: From past to future. Mutat. Res. - Genet. Toxicol. Environ. Mutagen. 607 (2006) 2-4.

[68] B. Miller, F. Pötter-Locher, A. Seelbach, H. Stopper, D. Utesch, S. Madle. Evaluation of the in vitro micronucleus test as an alternative to the in vitro chromosomal aberration assay: Position of the GUM working group on the in vitro micronucleus test. Mutat. Res. - Rev. Mutat. Res. 410 (1998) 81-116.

[69] L. Vian, P. Van Hummelen, N. Bichet, D. Gouy, M. Kirsch-Volders M. Evaluation of hydroquinone and chloral hydrate on the in vitro micronucleus test on isolated lymphocytes. Mutat. Res. 334 (1995) 1-7.

[70] K. Harrington-Brock, C.L. Doerr, M.M. Moore. Mutagenicity of three disinfection byproducts: di- and trichloroacetic acid and chloral hydrate in L5178Y/TK +/- (-)3.7.2C mouse lymphoma cells. Mutat. Res. 413 (1998) 265-276.

[71] C.C. Furnus, M.A. Ulrich, M.C. Terreros, F.N. Dulout. The induction of aneuploidy in cultured Chinese hamster cells by propionaldehyde and chloral hydrate. Mutagenesis 5 (1990) 323-326.

[72] S. Bonatti, Z. Cavalieri, S. Viaggi, A. Abbondandolo. The analysis of 10 potential spindle poisons for their ability to induce CREST-positive micronuclei in human diploid fibroblasts. Mutagenesis 7: (1992) 111-114.

[73] R.J. Bull, J.R. Meier, M. Robinson, H.P. Ringhand, R.D. Laurie, J.A. Stober. Evaluation of 
mutagenic and carcinogenic properties of brominated and chlorinated acetonitriles: byproducts of chlorination. Fundam. Appl. Toxicol. 5 (1985) 1065-1074.

[74] M.J. Plewa, Y. Kargalioglu, D. Vankerk, R.A. Minear, E.D. Wagner. Mammalian cell cytotoxicity and genotoxicity analysis of drinking water disinfection by-products. Environ. Mol. Mutagen. 40 (2002) 134-142.

[75] J. Pals, J.K. Ang, E.D. Wagner, M.J. Plewa. Biological mechanism for the toxicity of haloacetic acid drinking water disinfection byproducts. Environ. Sci. Technol. 45 (2011) $5791-5797$.

[76] K. Chisholm, A. Cook, C. Bower, P. Weinstein P. Risk of birth defects in Australian communities with high levels of brominated disinfection by-products. Environ. Health Perspect. 116 (2008) 1267-1273. 


\section{Figure Legends}

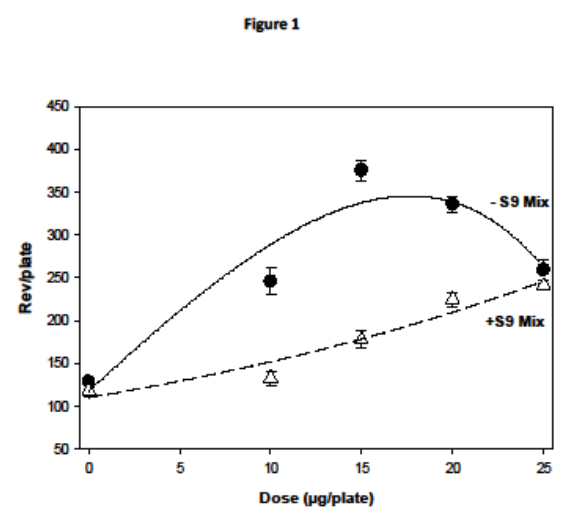

Figure 1. Dose-response relationship of BH on the tester strain TA100 with and without the S9 mix. Non-linear regression analyses were performed as described in the methods section.

In the absence of the S9 mix (dark circles, black line), $\mathrm{r}^{2}=0.90, \mathrm{P}<10^{-5}$ and $\mathrm{P}_{\text {error }}=0.65$

In presence of the S9 mix (white triangles, dashed line), $r^{2}=0.90, P<10^{-5}$ and $P_{\text {error }}=0.07$ 

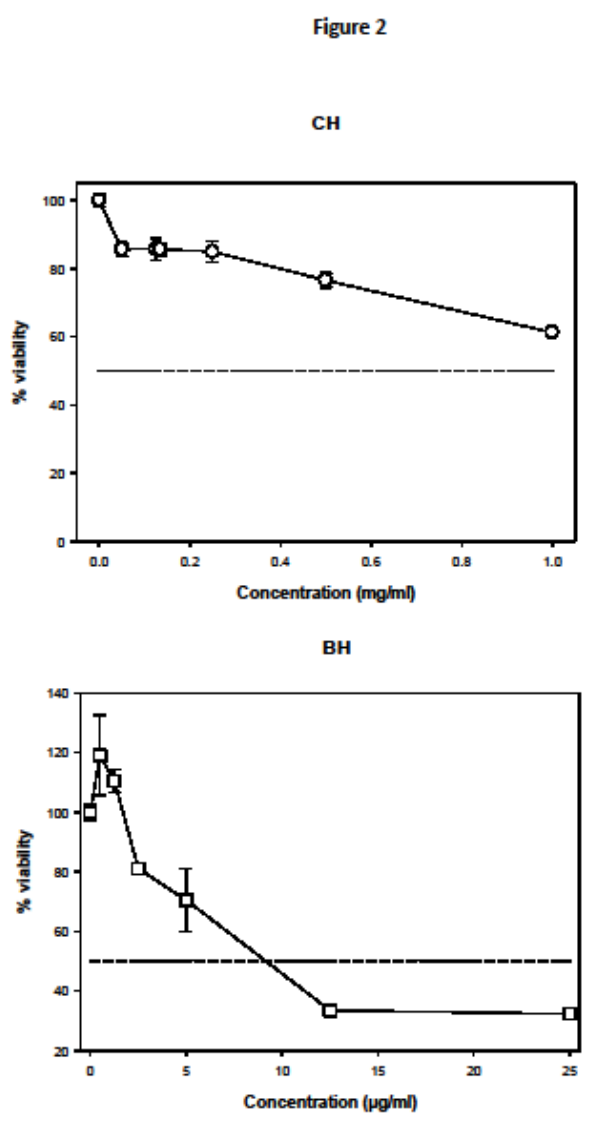

Figure 2. Cytotoxicity assay (WST-1) on $\mathrm{CHO}$ cells for $\mathrm{CH}$ and $\mathrm{BH}$. The dashed line represents the $50 \%$ viability 

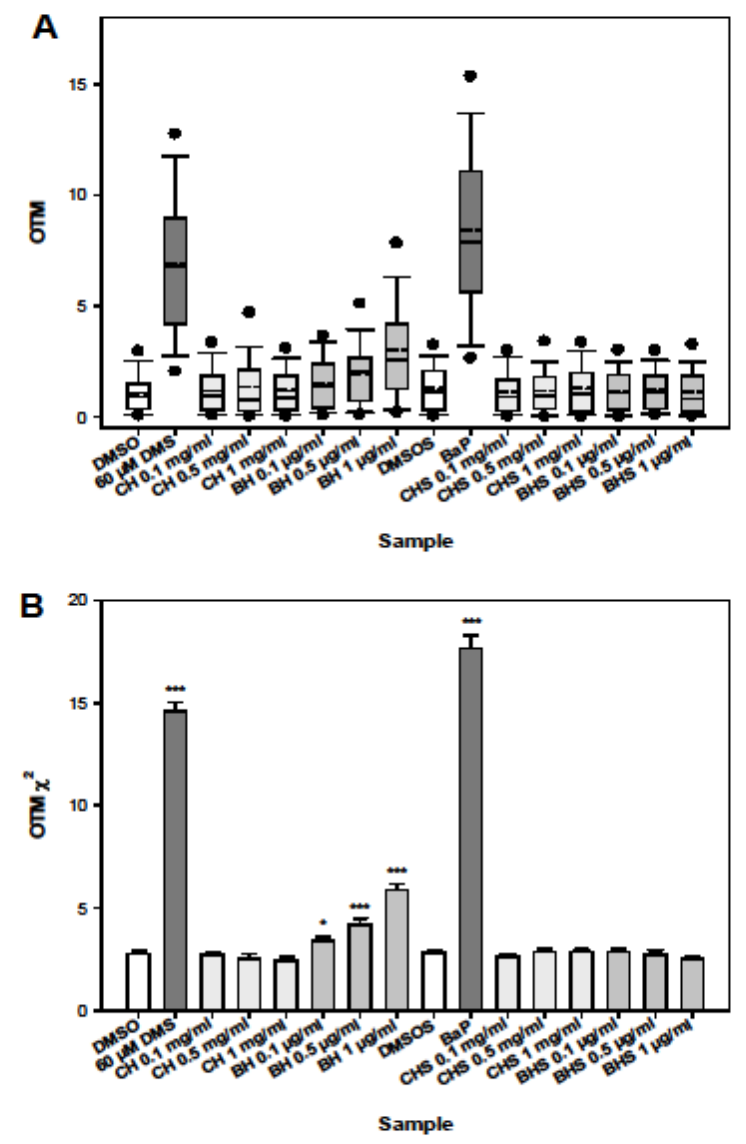

Figure 3. Results of the Comet assay on $\mathrm{CHO}$ cells for $\mathrm{CH}$ and $\mathrm{BH}$.

A. Box-and-Whisker plot of the distributions of OTM values. The graphs display the $25^{\text {th }}$ and $75^{\text {th }}$ percentiles (lower and upper sides of boxes), the $5^{\text {th }}$ and $95^{\text {th }}$ percentiles (error bars), the lowest and highest OTM values (black circles), the median (black line), and the mean (dashed line). Each condition includes 100 OTM values.

B. Histogram of OTM $\chi 2$ values.

DMSO: dimethylsulfoxide; DMS: dimethylsulfate; BaP: benzo[a]pyrene; $\mathrm{BH}$ : bromal hydrate; $\mathrm{CH}$ : chloral hydrate; S: treatment with S9 mix

*: $P<0.05 ; * * *: P<0.001$ 
Figure 4

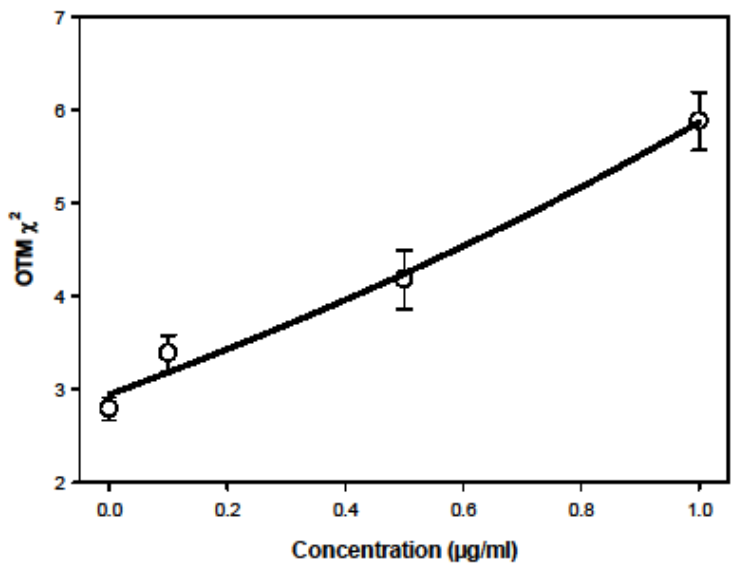

Figure 4. Dose-response relationship of $\mathrm{BH}$ on $\mathrm{CHO}$ cells with the comet assay.

A non-linear regression analysis was performed as described in the methods section $r^{2}=0.96, P<10^{-5}$ and $P_{\text {error }}=0.07$. The maximal calculated genotoxic activity was 3.68 OTM $\chi^{2} / \mu \mathrm{g}$. 


\section{Table Legends}

Table 1. Names, CAS numbers, and chemical structures of $\mathrm{CH}$ and $\mathrm{BH}$

\begin{tabular}{|c|c|c|}
\hline Name & CAS Number & Structure \\
\hline $\begin{array}{c}\text { Chloral Hydrate } \\
\text { 2,2,2-Trichloro-1,1-ethanediol } \\
\text { Trichloroacetaldehyde hydrate }\end{array}$ & $302-17-0$ & $\mathrm{Cl}$ \\
\hline $\begin{array}{c}\text { Bromal Hydrate } \\
\text { 2,2,2-Tribromo-1,1-ethanediol } \\
\text { Tribromoacetaldehyde hydrate }\end{array}$ & $507-42-6$ & $\mathrm{Br}$ \\
\hline
\end{tabular}


Table 2. Complete results of the Ames test for $\mathrm{CH}$ and $\mathrm{BH}$ with and without the $\mathrm{S} 9 \mathrm{mix}$

\begin{tabular}{|c|c|c|c|c|c|c|c|c|c|}
\hline & & \multicolumn{8}{|c|}{ Strain (rev/plate) } \\
\hline & & \multicolumn{2}{|c|}{ TA97a } & \multicolumn{2}{|c|}{ TA98 } & \multicolumn{2}{|c|}{ TA100 } & \multicolumn{2}{|c|}{ TA102 } \\
\hline Sample & Dose $^{a}$ & -59 & +59 & -59 & +59 & -59 & +59 & -59 & +59 \\
\hline \multicolumn{10}{|l|}{$\mathrm{CH}$} \\
\hline & 0 & $151 \pm 4$ & $151 \pm 16$ & $22 \pm 3$ & $36 \pm 4$ & $178 \pm 12$ & $173 \pm 12$ & $521 \pm 14$ & $504 \pm 16$ \\
\hline & 20 & $131 \pm 4$ & $162 \pm 6$ & $29 \pm 5$ & $29 \pm 3$ & $179 \pm 13$ & $177 \pm 15$ & $500 \pm 6$ & $441 \pm 4$ \\
\hline & 30 & $136 \pm 12$ & $145 \pm 11$ & $23 \pm 3$ & $29 \pm 4$ & $179 \pm 11$ & $182 \pm 10$ & $495 \pm 19$ & $468 \pm 12$ \\
\hline & 40 & $141 \pm 14$ & $154 \pm 10$ & $30 \pm 3$ & $25 \pm 4$ & $174 \pm 3$ & $170 \pm 7$ & $521 \pm 4$ & $502 \pm 14$ \\
\hline & 50 & $144 \pm 2$ & $144 \pm 11$ & $20 \pm 6$ & $26 \pm 4$ & $177 \pm 8$ & $178 \pm 17$ & $518 \pm 6$ & $502 \pm 20$ \\
\hline \multicolumn{2}{|c|}{ Pos. Ctrl ${ }^{b}$} & $258 \pm 10$ & $1198 \pm 112$ & $94 \pm 7$ & $642 \pm 18$ & $2119 \pm 13$ & $1312 \pm 1$ & $1939 \pm 30$ & $863 \pm 33$ \\
\hline \multicolumn{10}{|l|}{$\mathrm{BH}$} \\
\hline & 0 & $139 \pm 13$ & $153 \pm 23$ & $20 \pm 4$ & $26 \pm 5$ & $126 \pm 4$ & $118 \pm 11$ & $521 \pm 10$ & $494 \pm 26$ \\
\hline & 20 & $168 \pm 11$ & $168 \pm 3$ & $24 \pm 1$ & $34 \pm 2$ & $245 \pm 20$ & $133 \pm 10$ & $480 \pm 18$ & $400 \pm 28$ \\
\hline & 30 & $163 \pm 21$ & $213 \pm 7$ & $33 \pm 5$ & $28 \pm 4$ & $375 \pm 14$ & $177 \pm 12$ & $502 \pm 4$ & $426 \pm 14$ \\
\hline & 40 & $164 \pm 6$ & $206 \pm 16$ & $32 \pm 4$ & $37 \pm 1$ & $336 \pm 12$ & $224 \pm 10$ & $506 \pm 6$ & $432 \pm 49$ \\
\hline & 50 & $120 \pm 8$ & $169 \pm 51$ & $32 \pm 6$ & $33 \pm 3$ & $259 \pm 14$ & $241 \pm 3$ & $521 \pm 8$ & $407 \pm 20$ \\
\hline \multicolumn{2}{|c|}{ Pos. Ctrl } & $199 \pm 1$ & $1039 \pm 50$ & $147 \pm 20$ & $639 \pm 10$ & $1677 \pm 6$ & $1516 \pm 39$ & $3617 \pm 152$ & $906 \pm 20$ \\
\hline
\end{tabular}

Pos. Ctrl: positive control

All data are the means \pm SD of three consecutive independent experiments.

Bold characters: statistically significant difference with the control by the Dunnett's test at $P<0.01$

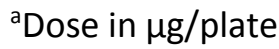

bPositive controls used in the absence of S9 mix were Acridine Mutagen (ICR191; $0.002 \mu \mathrm{g} /$ plate), 2,4,7-

Trinitro-9-fluorenone (TNF; $0.002 \mu \mathrm{g} /$ plate), sodium azide ( $\mathrm{NaN}_{2} ; 10 \mu \mathrm{g} /$ plate), Mitomycin C (0.002

$\mu \mathrm{g} /$ plate) in TA97a, TA98, TA100, and TA102 strains, respectively. In the presence of S9 mix, benzo[a]pyrene (BaP; $1 \mu \mathrm{g} /$ plate) was used as a positive control in the four tester strains. 
Table 3. Complete results of the micronucleus assay on $\mathrm{CH}$ and $\mathrm{BH}$ with and without the $\mathrm{S} 9 \mathrm{mix}$

\begin{tabular}{|c|c|c|c|c|c|c|c|}
\hline \multirow[b]{2}{*}{ Sample } & \multirow[b]{2}{*}{$\begin{array}{l}\text { Concentration } \\
(\mu \mathrm{g} / \mathrm{ml})\end{array}$} & \multicolumn{3}{|c|}{ Without S9 Mix } & \multicolumn{3}{|c|}{ With S9 Mix } \\
\hline & & PI (\%) & $\begin{array}{c}\text { Mean MBC } \\
(\%)\end{array}$ & $\mathrm{P}^{*}$ & PI (\%) & $\begin{array}{c}\text { Mean MBC } \\
(\%)\end{array}$ & $p^{*}$ \\
\hline Neg. Ctrl & 0 & 100 & $9.5 \pm 0.7$ & & 100 & $10.5 \pm 0.7$ & \\
\hline Pos. Ctrl & $0.05^{a}, 5^{b}$ & 98 & $30 \pm 2.8$ & $<0.001$ & 98 & $23.5 \pm 2.1$ & $<0.01$ \\
\hline DMSO & $1 \%$ & 95 & $8.5 \pm 0.7$ & NS & 99 & $9.5 \pm 0.7$ & NS \\
\hline \multirow{6}{*}{$\mathrm{BH}$} & 0.1 & 95 & $10 \pm 1.4$ & NS & 97 & $10 \pm 1.4$ & NS \\
\hline & 0.25 & 86 & $10 \pm 2.8$ & NS & 95 & $10.5 \pm 0.7$ & NS \\
\hline & 0.5 & 82 & $10.5 \pm 0.7$ & NS & 95 & $11.5 \pm 0.7$ & NS \\
\hline & 1 & 75 & $11 \pm 1.4$ & NS & 84 & $12.5 \pm 0.7$ & NS \\
\hline & 2.5 & toxic & - & - & 72 & $14 \pm 2.8$ & NS \\
\hline & 5 & toxic & - & - & toxic & - & - \\
\hline \multirow{7}{*}{$\mathrm{CH}$} & 0.5 & 99 & $10.5 \pm 0.7$ & NS & 97 & $10.5 \pm 0.7$ & NS \\
\hline & 1.25 & 96 & $11.5 \pm 0.7$ & NS & 94 & $11 \pm 1.4$ & NS \\
\hline & 2.5 & 92 & $10.5 \pm 0.7$ & NS & 89 & $10 \pm 2.8$ & NS \\
\hline & 5 & 88 & $10.5 \pm 2.1$ & NS & 85 & $10.5 \pm 0.7$ & NS \\
\hline & 12.5 & 79 & $10 \pm 1.4$ & NS & 71 & $13 \pm 1.4$ & NS \\
\hline & 25 & 72 & $10.5 \pm 0.7$ & NS & toxic & - & - \\
\hline & 50 & toxic & - & - & toxic & - & - \\
\hline
\end{tabular}

Neg. Ctrl: negative control

Pos. Ctrl: positive control

NS: non-significant

PI: proliferative Index expressed in \%, when less than 50\% the cytotoxicity impairs the evaluation of genotoxicity (denoted as toxic in the table)

Mean MBC: the mean number of micronucleated binucleated cells in 1000 binucleated cells

${ }^{a}$ concentration of Mitomycin $\mathrm{C}$, the positive control in the absence of $\mathrm{S} 9 \mathrm{mix}{ }^{\mathrm{b}}$ concentration of $\mathrm{BaP}$, the positive control in the presence of $\mathrm{S} 9 \mathrm{mix}$

*compared with negative controls (chi-squared test) 